\title{
A Study of The Effect of Fractionation on Phytochemical Composition And In Vitro Antimicrobial Activity of Methanol Extract of Garcinia Kola (Heckel) Seeds on Some Bacterial Isolates
}

\author{
BB Bukar ${ }^{*}$ JF Adurogboye ${ }^{1}$ and KD Falang ${ }^{1}$ \\ ${ }^{1}$ Department of Pharmacology and Toxicology, \\ University of Jos, P.M.B 2084, Jos, Plateau state, Nigeria \\ "Corresponding Author \\ E-mail: bukata33@yahoo.com \\ DOI: $10.31364 / \mathrm{SCIRJ} / \mathrm{v} 7 . \mathrm{i} 5.2019 . P 0519649$ \\ http://dx.doi.org/10.31364/SCIRJ/v7.i5.2019.P0519649
}

\begin{abstract}
Objective: The objective of this study is to investigate the effect of fractionation of the crude methanol extract of Garcinia kola (Heckel) seeds on phytochemical constituents and in vitro antimicrobial activity.

Method: Fractionation was carried out using the solvent portioning method with solvents of different polarities. Phytochemical analysis was done by use of specific analytical test for each constituent. The minimum inhibitory concentration was determined by the broth microdilution assay while the minimum bactericidal concentration was carried out using the agar well diffusion method.

Results: The different fractions exhibited differences in their composition of the phytochemical constituents. This observation was however not dependent on the sequence of the polarity of the solvents. The acetone fraction presented similar phytochemicals compared with those of the crude methanol extract. The n-hexane fraction presented the least phytochemicals.

The crude methanol fraction exhibited antibacterial activity against all the isolates at the concentration of $200 \mathrm{mg} / \mathrm{ml}$, suggesting that fractionation may not be of any added advantage on the antibacterial activity. The antibacterial activity exhibited by the fractions against all the isolates were significant lower compared to that due to the standard antibiotic, gentamicin, $4 \mathrm{mg} / \mathrm{ml}(\mathrm{P}<0.05)$. Similarly, it was shown that the antibacterial activity of each of the fraction was dose-dependent, with larger zones of inhibition corresponding to higher concentrations $(\mathrm{P}<0.05)$. The acetone fraction exhibited highest antibacterial activity on $S$ aureus with a zone of inhibition of inhibition of $20.5 \pm 7.1 \mathrm{~mm}$ at the concentration of $200 \mathrm{mg} / \mathrm{ml}$. This was significantly lower compared to $31.5 \pm$ $6.2 \mathrm{~mm}$ due to gentamicin, $4 \mathrm{mg} / \mathrm{ml}(\mathrm{P}<0.05)$. The lowest antibacterial activity was exhibited at $200 \mathrm{mg} / \mathrm{ml}$ was seen with the methanol fraction on E coli with a zone of inhibition of $4.3 \pm 1.2 \mathrm{~mm}$ and it was the only fraction with effect against this isolate. The n-hexane fraction did not exhibit any visible antimicrobial activity on all the isolates.

Conclusion: Fractionation of the crude methanol extract revealed the antibacterial activity of the fractions with the acetone fraction more effective on $S$ aureus than the crude extract. The finding generally confirms and validate the traditional claims and other scientific findings that Garcinia kola possesses principles that are antibacterial. This could therefore justify its traditional use in some infectious diseases and the need for further investigations.
\end{abstract}

\section{Keywords: Garcinia kola, fractionation, antibacterial, ethno-medicine, solvents, in vitro}

\section{INTRODUCTION}

Medicinal plants have served as sources of raw materials for the extraction of active molecules utilized in the synthesis of useful drugs. Natural products and their semi-synthetic derivatives presently represent about $50 \%$ of drugs used in clinical practice and about $11 \%$ of the 252 drugs considered essential by the World Health Organization (WHO) are exclusively of plant origins with a significant portion of synthetic drugs being manufactured from natural precursors [1]. Yet, this is just the tip of the iceberg when considered in larger perspective. According to reports, of the estimated 250-500 thousand living plant species, only $6-15 \%$ has been explored in terms of pharmacological and phytochemical investigations [2]. This therefore presents a vast source of bioactive molecules compared to the existing ones already discovered. For tropical and sub-tropical Africa, its biodiversity makes it an important source of plants of medicinal that could be effective in combating diseases, most especially those of infectious origins. This 
may help curb the trend of widespread bacteria resistance to antibiotics [3]. Therefore, natural products have become valuable targets for biological screening based on their Ethno-medical uses. This is more so because many infectious diseases are known to have been treated with herbal remedies throughout the history of mankind [4]

Garcinia kola, commonly called bitter kola, is an example of such medicinal plants that have recently attracted attention in terms of its medicinal uses. It is traditionally claimed to have many beneficial effects and is highly valued in African ethno-medicine for both social and medicinal uses. Bitter kola is believed to be an important source for new chemical substances with potential therapeutic properties [5].

Although the plant parts such as the leave, stem, root and bark of Garcinia kola have been commonly used in folk medicine, remarkable priority is being given to the seeds of the plant. The seeds are consumed almost in an addictive manner for social and medicinal purposes and even in West African sub-region. It is commonly presented during social functions as part of traditional African hospitality and as a symbol of respect where it is presented to the elders. Due to its attributes that is traditionally related to good health, Garcinia kola seeds are consumed by both the old and young and by both men and women alike..

Some reported physiological and pharmacological activities of Garcinia kola as part of the scientific investigation of the traditional claims include hepato-protective activities, aphrodisiac and fertility [6,7]. The seed extract has been reported to possess antihepatotoxic and anti-diarrheal activities [8,9]. Also, it has been investigated and found to possess anti-inflammatory, anti-oxidant and anti-allergy activity. G. Kola has also been demonstrated to show purgative activity due to its possession of a company called hydroxycitric acid. This has led to claims that Garcinia kola can be used as an anorectic agent to reduce weight in obesity. The nut has been used in the treatment of bronchitis and throat infections $[10,11]$. G. kola has also been reported to have anti-hypertensive effects and cardiovascular protective effect against cholesterol [12]. Garcinia kola showed has been reported to possess cytoprotective and hypoglycaemic activities in streptozocin and alloxan-induced diabetes in rats [14. 15].

The aim of the present study is to investigate effect of fractionation of the crude methanol seed extract of Garcinia kola on phytochemical composition and in vitro antibacterial activities against some bacterial isolates. The findings may perhaps confirm or refute the earlier reported antibacterial activity of the crude extract.

\section{MATERIALS AND METHOD}

\section{Preparation of Extract}

Garcinia kola seeds were purchased from a reputable dealer in Terminus market in Jos metropolis. The seeds were re-authenticated by a taxonomist at the Federal College of Forestry, Jos, Plateau state and a herbarium voucher specimen (number FHJ 429-17) was prepared.

The seeds were washed, de-husked and carefully cut in small pieces with a sharp knife to enhance drying. They were then dried under shade in the laboratory. Thereafter, they were grounded to powder and extracted according to the method described by Adegboye et al [16].

$250 \mathrm{~g}$ of the powdered seed was extracted continuously with methanol $(80 \%)$ in a soxhlet extractor for 25 hours at $65{ }^{0} \mathrm{C}$. The extract was evaporated to dryness in a vacuum evaporator at $50{ }^{\circ} \mathrm{C}$ until a constant yield of $52.65 \mathrm{~g}$ (representing $21.06 \%$ ) following repeated weighing was obtained. The extract was reconstituted in normal saline for the purpose of the experiment.

\section{Fractionation of the crude extract}

The solvent partitioning method using partition coefficient of organic solvents with different polarities described by Otsuka [17] was used with slight modifications.

$25 \mathrm{~g}$ of the methanol crude extract was reconstituted with $80 \%$ methanol and $500 \mathrm{ml}$ of $\mathrm{n}$-hexane was added followed by continuous stirring for 1 hour. The mixture was allowed to stand for 24 hours after which it was decanted and filtered. The filtrate was dried in an open air and thereafter, stored as the n-hexane fraction.

The residue was mixed with $500 \mathrm{ml}$ of chloroform and stirred continuously for 1 hour. The resulting mixture was allowed to stand for 24 hours, and thereafter it was decanted and filtered. The filtrate was dried in an open air to obtain the chloroform fraction.

The same procedure was successively used to obtain the ethyl acetate and acetone fractions. The percentage yield of each dried product of the fractionation and the crude residue was calculated. They were stored in a refrigerator maintained at a temperature of between 3 and $5{ }^{\circ} \mathrm{C}$ until the commencement of the experiment.

\section{Phytochemical Analyses of the fractions}

\section{Test for Alkaloids}

The method described by Trease and Evans [18] was used. $0.5 \mathrm{~g}$ of the fraction was weighed and mixed with $3 \mathrm{ml}$ of $1 \%$ aqueous hydrochloric acid (HCL) on a stream bath and stirred very well and the solution thereafter filtered with Whatman's filter paper to get a clean filtrate. Few drops of Wagner's reagent, Dragendoff's reagent and picric acid solution were separately treated with $1 \mathrm{ml}$ each of the filtrate. They were then repeatedly observed for precipitation and confirmation of the presence of any alkaloid. 
Test for Saponins

The test was done using the method described by Trease and Evans [18]. $0.5 \mathrm{~g}$ of the fraction was weighed and dissolved in $5 \mathrm{ml}$ of distilled water in a test tube. It was then shaken very well and then warmed for 5 minutes while observing for the formation of froths as evidence for the presence of saponins.

\section{Test for Tannins}

$0.5 \mathrm{~g}$ of the fraction was dissolved in $1 \mathrm{ml}$ of distilled water. It was gently shaken, filtered and mixed with $5 \%$ ferric chloride. The mixture was observed for a blue-green precipitate as evidence for tannins [17].

\section{Test for Anthraquinones}

$0.5 \mathrm{~g}$ of the fraction was weighed in a test tube. $5 \mathrm{ml}$ of chloroform was added and shaken for 5 minutes. The solution was then filtered and the resulting filtrate mixed with equal volume of $10 \%$ ammonium solution. Thereafter, the mixture was observed for a red coloration in the ammonical layer as evidence for the presence of anthraquinones Joshi et al [19].

\section{Test for Glycosides}

$100 \mathrm{mg}$ of the fraction was weighed in a test tube and $2.5 \mathrm{ml}$ of a diluted sulphuric acid was added and immersed for $15 \mathrm{minutes}$ in a boiling water contained in a bath. It was then allowed to cool and thereafter neutralized with 2 ml of $20 \%$ potassium hydroxide. 5 ml of Fehling's solution A and B was added and boiled for 3 minutes while observing for a brick-red precipitate as evidence of the presence of glycosides.

\section{Test for Carbohydrates}

$100 \mathrm{mg}$ of the fraction was dissolved in $3 \mathrm{ml}$ of distilled water in an inclined test tube and then mixed with 3 drops of Molisch reagent. Thereafter, $1 \mathrm{ml}$ of a concentrated sulphuric acid was carefully added down the side of the test tube such that the acid forms a layer beneath the aqueous solution without mixing or shaking. It was then observed for a reddish ring precipitate at the junction of the liquid as evidence for the presence of carbohydrates [18].

\section{Test for Steroids}

$100 \mathrm{mg}$ of the fraction was dissolved in $2 \mathrm{ml}$ of chloroform and $1 \mathrm{ml}$ of concentrated sulphuric acid was added. The mixture was allowed to stand and observed for a brown coloration as evidence of the presence of steroids [20].

\section{Test for Flavonoids}

$2 \mathrm{~g}$ of the fraction was dissolved in $10 \mathrm{ml}$ of acetone in a conical flask and then immersed for 3 minutes in warm water contained in a bath. The mixture was then filtered immediately and $5 \mathrm{ml}$ of the filtrate was mixed with lead sub-acetate solution and observed for a yellow precipitate as evidence for the presence of flavonoids.

\section{Test for Terpenes}

$100 \mathrm{mg}$ of the fraction was dissolved in $2 \mathrm{ml}$ of chloroform and $3 \mathrm{ml}$ of a concentrated sulphuric acid. The mixture was allowed to stand and observed for the presence a reddish-brown ring as evidence for the presence of terpenes [21].

\section{Preparation of Media for In-Vitro Anti-Microbial Screening Test}

\section{Muller Hutton Agar}

A $10.64 \mathrm{~g}$ of Muller Hutton agar powder was weighed and transferred into a $500 \mathrm{ml}$ conical flask and then $280 \mathrm{mls}$ of distilled water was added. This mixture was then heated to boiling to facilitate the dissolution of the powder with water. A $20 \mathrm{ml}$ volume of the resultant clear mixture was then transferred into bijou bottles until 28 bottles of molten agar was gotten. The process was repeated to make a total of 56 bottles of molten agar. These bottles were places in an autoclave and heated at $120{ }^{\circ} \mathrm{C}$ to sterilize for 15 minutes. They were then refrigerated at $-5{ }^{\circ} \mathrm{C}$

\section{Nutrient Broth}


Using a weighing balance, $2.0 \mathrm{~g}$ of the nutrient broth was weighed and transferred into a $500 \mathrm{ml}$ flask. $280 \mathrm{ml}$ of water was added into the beaker and the mixture swirled until complete dissolution was attained. This was then placed in bijou bottles at $10 \mathrm{ml}$ per bottle and autoclaved at $120{ }^{\circ} \mathrm{C}$ for 15 minutes. The sterile nutrient broth was stored in a refrigerator at $-5^{\circ} \mathrm{C}$.

\section{Preparation of Sub-Cultures}

Following the identification of the various microorganisms, a sub-culture of Staphylococcus aureus was made using a micro pipette. This procedure was performed in a fume cupboard. Using the micro pipette, $0.1 \mathrm{ml}$ of a stock broth culture of Staphylococcus aureus was taken and introduced into a bottle of sterile broth. This preparation was then incubated at $37{ }^{\circ} \mathrm{C}$ for 24 hours and a turbid broth after 24 hours indicated the growth of the Staphylococcus aureus strain in the nutrient broth. This procedure was also used in the preparation of Bacillus subtilis, Escherichia coli and Salmonella typhi sub-cultures.

\section{Reconstitution of the Fractions and Serial Dilution}

A $200 \mathrm{mg} / \mathrm{ml}$ concentration was prepared by weighing $2 \mathrm{~g}$ of the fraction and dissolving it in $10 \mathrm{ml}$ of distilled water with $2 \mathrm{ml}$ of Tween 80. The resulting mixture was stirred to attain an even mixture. Serial dilutions were made successively to obtain concentrations of $100 ; 50 ; 25$ and $12.5 \mathrm{mg} / \mathrm{ml}$ of the fractions of chloroform, $\mathrm{n}$-hexane, acetone and ethyl acetate and the pure methanol extract respectively. In the same manner, a standard antibiotic (Gentamicin) of concentration $40 \mathrm{mg} / \mathrm{ml}$ was serially diluted to get a concentration of $4 \mathrm{mg} / \mathrm{ml}$.

\section{Preparation of the Petri Dishes}

The petri dishes were sterilized by heating in an oven for 1 hour. The bottled agar was then melted in the autoclave. The agar was then removed from the auto clave and the petri dishes from the oven. The table was disinfected with $99 \%$ alcohol. Following this, a spirit lamp was placed on the table and lit. A beaker containing $99 \%$ alcohol and a disinfection jar was also made available [22].

\section{Pilot Sensitivity Test}

A pilot sensitivity test of the concentrations to be used was carried out in two of the isolates to establish the effectiveness.

\section{Minimum Inhibitory Concentration Assay}

This was carried out using the broth micro-dilution method as described by Ndukwe et al [23]. Fresh nutrient broth was prepared and poured into test tubes and labelled according to the different concentrations of the fractions. $0.5 \mathrm{ml}$ of a 24-hour sub culture was introduced into each test-tube. Following this, $0.5 \mathrm{ml}$ of the various concentrations were added to their appropriate test tubes. This was then incubated for 24 hours at $37^{\circ} \mathrm{C}$ and then observed for turbidity. The absence of turbidity was recorded as "no growth" and presence of turbidity as "bacterial growth" [24].

\section{The Minimum Bactericidal Concentration (MBC) Test}

The spirit lamp was lit, and a wired loop heated in the flame to red heat and then allowed to cool. The wired loop was then used to streak the surface of the inhibited zones and then used to inoculate a bottle of sterile nutrient broth. The bottle was then labelled according to the standard drug, concentrations of the fractions and organism which corresponds to where the zone of inhibition was seen. This was repeated for all zones of inhibited growth [24]. The inoculated broth bottles where then placed in an incubator and incubated for 24 hours, after which they were observed for turbidity (growth) or non-turbidity (absence of growth).

\section{Statistical Analysis}

Results were statistically analysed using the Student's t-test at a significant level of $\mathrm{P}=0.05$.

\section{RESULTS}

\section{Phytochemical Analysis}

The results of the phytochemical analysis of each fraction are shown on Table 1. The result revealed the presence of Alkaloids, Tannins, Flavonoids, Carbohydrates, Terpenes, Saponins, Cardiac glycosides and steroids. The phytochemical compositions may perhaps account for some of the physiological and pharmacological activities of the methanol extract of Garcinia kola seed.

The fractions showed an accumulation of phytochemicals which does not correspond to the polarity profile of the solvents used. Nhexane ( $0.9 \%$ polarity) and Chloroform (25.9) fractions showed more non-polar constituents such as terpenes and steroids compared to acetone (35.5) and ethyl acetate (23.0) fractions which contain alkaloids, flavonoids, saponins and tannins. However, the more 
polar solvents, methanol (76.2) and acetone (35.5) contains all the constituents at varying degrees. Anthraquinones were absent in all the fractions.

Pilot Sensitivity Test

The results of the pilot sensitivity test are presented on plates 1 and 2 . The results showed that $S$ typhi and $B$ subtilis were sensitive to the antibacterial activity of the standard antibiotic, gentamicin $4 \mathrm{mg} / \mathrm{ml}$, methanol and ethyl acetate fraction at $200 \mathrm{mg} / \mathrm{ml}$.

\section{Minimum Inhibitory Concentration (MIC)}

The MIC for the fractions are separately shown on table 2 (methanol), 4 (n-Hexane), 6 (chloroform), 8 (acetone) and 10 (ethyl acetate).

$S$ aureus was more sensitive to the inhibitory action of the methanol fraction with MIC of $50 \mathrm{mg} / \mathrm{ml}$ while $S$ typhi, $B$ subtilis and $E$ coli had relatively higher MIC of $200 \mathrm{mg} / \mathrm{ml}$. There was no inhibitory effect demonstrated against all the isolates at the lower concentrations of 25 and $12 \mathrm{mg} / \mathrm{ml}$ of the methanol fraction (table 2).

All the isolates were not sensitive to the inhibitory action of the n-hexane fraction at the concentrations used for this study as there were no observed zones of inhibition (table 4).

The chloroform fraction had inhibitory effect only on $S$ typhi and B subtilis at the highest concentration of $200 \mathrm{mg} / \mathrm{ml}$ (table 6).

Table 8 shows the MIC of the acetone fraction on the isolates. $S$ typhi and $S$ aureus were more sensitive with MIC of $50 \mathrm{mg} / \mathrm{ml}$ of the fraction while $B$ subtilis and $E$ coli were less sensitive with a higher MIC of $200 \mathrm{mg} / \mathrm{ml}$. There was growth of all the isolates at concentrations of 25 and $12.5 \mathrm{mg} / \mathrm{ml}$ of the acetone fraction (table 8 )

On table 10 is shown the MIC of the ethyl acetate fraction. B subtilis had least MIC of $25 \mathrm{mg} / \mathrm{ml}$ while $E$ coli had the highest with 200 $\mathrm{mg} / \mathrm{ml}$. All the isolates were not sensitive to the inhibitory effect of this fraction at the concentration of $12.5 \mathrm{mg} / \mathrm{ml}$ (table 10$)$

Generally, the lowest MIC values are seen with the ethyl acetate fraction at $25 \mathrm{mg} / \mathrm{ml}$ against Bacillus subtilis. The Acetone fraction showed a minimum inhibitory concentration at $50 \mathrm{mg} / \mathrm{ml}$ against Staphylococcus aureus. The Chloroform fraction showed inhibition at a concentration of $200 \mathrm{mg} / \mathrm{ml}$, while the n-hexane fraction didn't show any visible inhibitory activity. The crude methanol fraction only showed inhibitory activity against $S$. aureus causing inhibition at a minimum concentration of $50 \mathrm{mg} / \mathrm{ml}$.

\section{Minimum Bactericidal Concentration (MBC)}

The in vitro antibacterial activity of the fractions are shown separately on table 3, 5, 7, 10, and 11 .

The methanol fraction had antibacterial activity against all the isolates at concentration of $200 \mathrm{mg} / \mathrm{ml}$ with the highest on $B$ subtilis with a zone of inhibition of $14.4 \pm 1.3 \mathrm{~mm}$ followed by $S$ aureus with $13.7 \pm 0.3 \mathrm{~mm}$ (table 3 ). These actions were respectively lower $(\mathrm{P}<0.05)$ compared to that of gentamicin $(4 \mathrm{mg} / \mathrm{ml})$. E coli was the least sensitive with a zone of $4.3 \pm 1.2 \mathrm{~mm}$ at the concentration of $200 \mathrm{mg} / \mathrm{ml}$. These effects appear to follow a similar pattern with those of the MIC (table 2)

The n-hexane fraction had no visible antibacterial activity against any of the isolates (table 5). This is similar to the result on the MIC (table 4).

The chloroform fraction had antibacterial activity against $S$ typhi $(11.3 \pm 0.2 \mathrm{~mm})$ and $B$ subtilis $(14.5 \pm 1.1 \mathrm{~mm})$ both at $200 \mathrm{mg} / \mathrm{ml}$. These activities were significantly lower $(\mathrm{P}<0.05)$ compared to that of gentamicin, $4 \mathrm{mg} / \mathrm{ml}($ table 7$)$.

Table 9 shows the antibacterial activity of the acetone fraction on each of the isolates. The activity of this fraction was highest against $S$ aureus with a minimum bactericidal concentration (MBC) of $50 \mathrm{mg} / \mathrm{ml}$. There was no observed antibacterial activity against $E$ coli at the doses used. The antibacterial activities at the highest dose of $200 \mathrm{mg} / \mathrm{ml}$ were significantly less compared to control (P < 0.05 ).

The ethyl acetate fraction demonstrated antibacterial activity against the isolates of $S$ aureus, $S$ typhi and $B$ subtilis at concentrations of 200 and $100 \mathrm{mg} / \mathrm{ml}$ (table 11). However, there was no visible antibacterial activity against E coli at all the doses used for this study. The $B$ subtilis isolate was more sensitive to the antibacterial effect of this fraction with an MBC of $25 \mathrm{mg} / \mathrm{ml}$. 
Table 1. Qualitative Phytochemical constituents of the fractions of methanol crude extract of Garcinia kola seeds

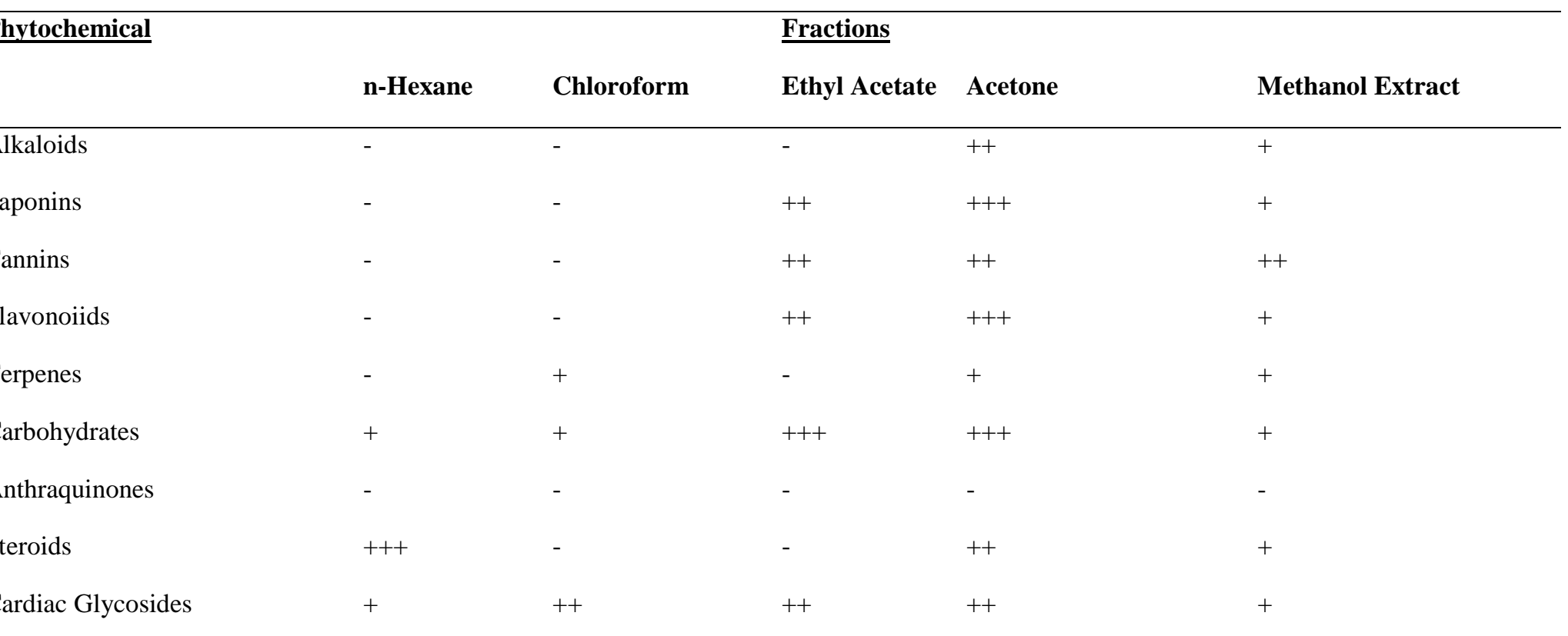

\footnotetext{
KEY : - = Not present,

$+=$ Present in small amount, $++=$ Moderately present,

$+++=$ Highly present
} 


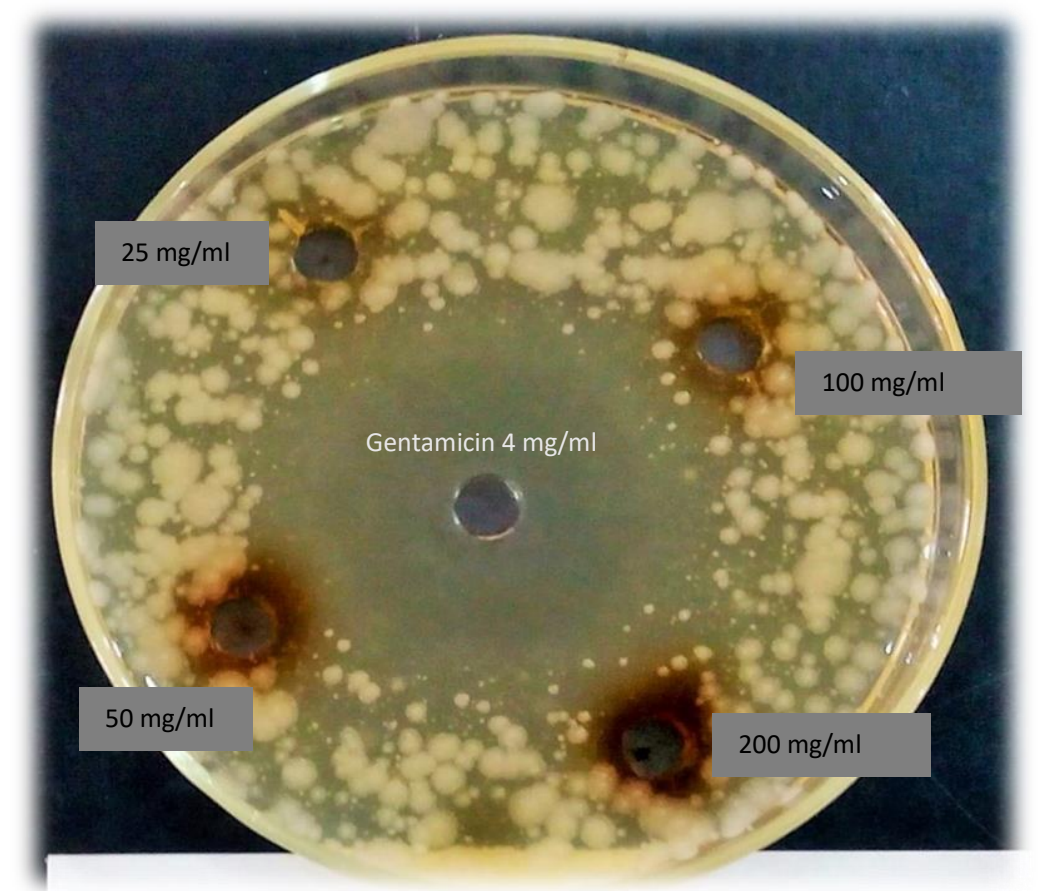

Plate 1. Effect of the Chloroform fraction of the crude methanol extract of Garcinia kola seed against Salmonella typhi

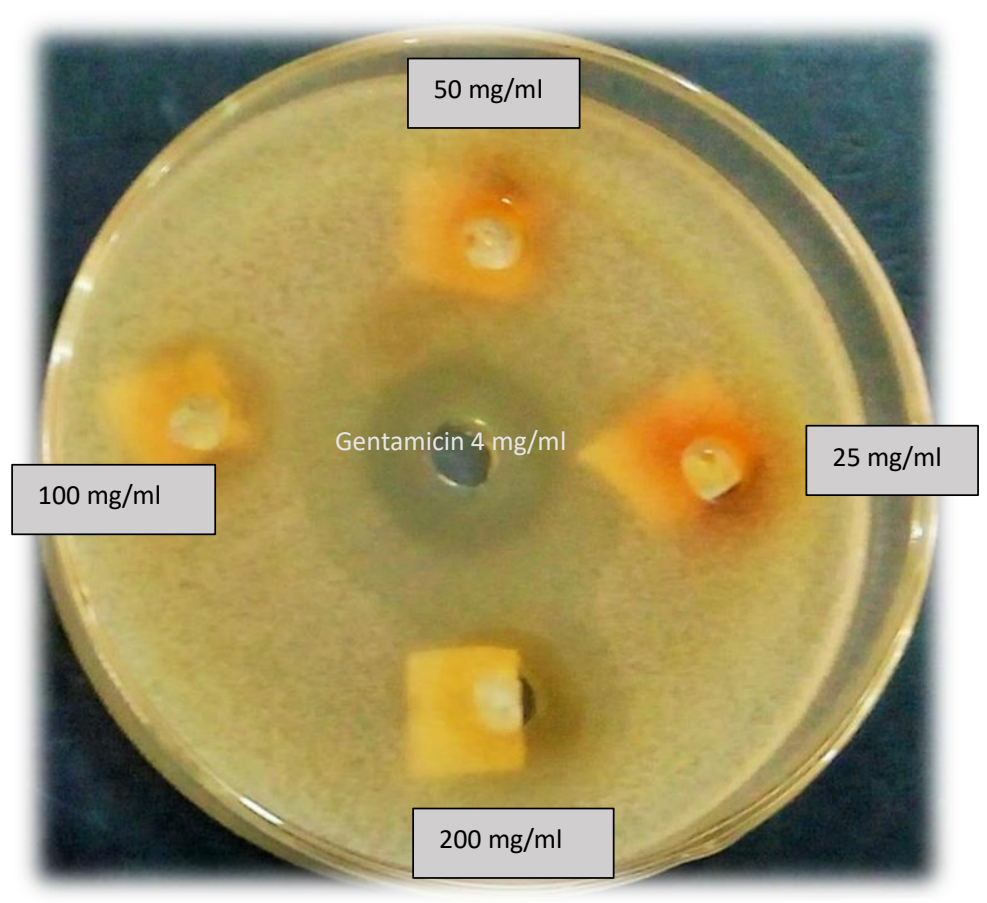

Plate 2. Effect of the Ethyl acetate fraction of the crude methanol extract of Garcinia kola seeds against Bacillus subtilis 
Table 2. In Vitro Minimum Inhibitory Concentration of the Crude Methanol fraction of Garcinia kola Seed extract in Some Bacterial Isolates

\begin{tabular}{|c|c|c|c|c|c|}
\hline \multirow[t]{2}{*}{ Organism } & \multicolumn{5}{|c|}{ Treatment $(\mathrm{mg} / \mathrm{ml})$} \\
\hline & 200 & 100 & 50 & 25 & 12.5 \\
\hline S. aureus & - & - & - & + & + \\
\hline S. typhi & - & + & + & + & + \\
\hline B. subtilis & - & + & + & + & + \\
\hline E. coli & - & + & + & + & + \\
\hline
\end{tabular}

Key: (-) - No growth

(+)- Presence of growth

Table 3: In Vitro Antibacterial activities of the Crude Methanol Fraction of Garcinia kola Seed Extract in Some Bacterial Isolates. Values are mean zone of inhibition $(\mathrm{mm}),(\mathrm{n}=3)$

\begin{tabular}{|c|c|c|c|c|c|c|}
\hline Organism & $\begin{array}{l}\text { Treatment }(1 \\
\text { Gentamicin } \\
\quad 4\end{array}$ & 200 & 100 & $\begin{array}{c}\text { Extract } \\
\quad 50\end{array}$ & 25 & 12.5 \\
\hline S. aureus & $31.5 \pm 1.2$ & $13.7 \pm 0.3^{*}$ & $9.1 \pm 1.1$ & $4.3 \pm 0.8^{\dagger}$ & - & - \\
\hline S. typhi & $39.1 \pm 0.7$ & $10.4 \pm 0.6$ & $2.6 \pm 0.3^{\dagger}$ & - & - & - \\
\hline B. subtilis & $25.8 \pm 2.1$ & $14.4 \pm 1.3^{*}$ & $8.1 \pm 2.2$ & $3.6 \pm 0.4^{\dagger}$ & - & - \\
\hline E. coli & $32.3 \pm 1.8$ & $4.3 \pm 1.2$ & - & - & - & - \\
\hline
\end{tabular}

Key: (-) - No inhibition

$* \mathrm{P}<0.05$ to control (gentamicin)

${ }^{\dagger} \mathrm{P}=<0.05$ compared to $200 \mathrm{mg} / \mathrm{ml}$ 
Table 4: In Vitro Minimum Inhibitory Concentration of the n-Hexane fraction of Garcinia kola Seed extract in Some Bacterial Isolates

\begin{tabular}{|c|c|c|c|c|c|}
\hline \multirow[t]{2}{*}{ Organism } & \multicolumn{5}{|c|}{ Treatment (mg/ml) } \\
\hline & 200 & 100 & 50 & 25 & 12.5 \\
\hline S. aureus & + & + & + & + & + \\
\hline S. typhi & + & + & + & + & + \\
\hline B. subtilis & + & + & + & + & + \\
\hline E. coli & + & + & + & + & + \\
\hline
\end{tabular}

Key: (-) - No growth

(+)- Presence of growth

Table 5: In Vitro antibacterial activity of the n-Hexane fraction of Garcinia kola Seed extract in Some Bacterial Isolates. Values are mean zone of inhibition $(\mathrm{mm}),(\mathrm{n}=3)$

\begin{tabular}{|c|c|c|c|c|c|c|}
\hline Organism & $\begin{array}{c}\text { Treatment ( } \\
\text { Gentamicin } \\
4\end{array}$ & 200 & 100 & $\begin{array}{c}\text { Extract } \\
50\end{array}$ & 25 & 12.5 \\
\hline S. aureus & $31.5 \pm 6.2$ & - & - & - & - & - \\
\hline S. typhi & $39.1 \pm 5.7$ & - & - & - & - & - \\
\hline B. subtilis & $25.8 \pm 5.1$ & - & - & - & - & - \\
\hline E. coli & $32.3 \pm 2.8$ & - & - & - & - & - \\
\hline
\end{tabular}

Key: (-) - No zone of inhibition 
Table 6: In Vitro Minimum Inhibitory Concentration of the Chloroform fraction of Garcinia kola Seed extract in Some Bacterial Isolates

\begin{tabular}{|l|ccccc|}
\hline Organism & \multicolumn{5}{|c|}{ Treatment (mg/ml) } \\
& $\mathbf{2 0 0}$ & $\mathbf{1 0 0}$ & $\mathbf{5 0}$ & $\mathbf{2 5}$ & $\mathbf{1 2 . 5}$ \\
\hline S. aureus & + & + & + & + & + \\
S. typhi & - & + & + & + & + \\
B. subtilis & - & + & + & + & + \\
E. coli & + & + & + & + & + \\
\hline
\end{tabular}

Key: (-) - No growth

(+)- Presence of growth

Table 7: In Vitro Antibacterial Activity of the Chloroform fraction of Garcinia kola Seed extract in Some Bacterial Isolates. Values are mean zone of inhibition $(\mathrm{mm}),(\mathrm{n}=3)$

\begin{tabular}{|c|c|c|c|c|c|c|}
\hline Chloroform & $\begin{array}{c}\text { Treatment ( } \\
\text { Gentamicin } \\
4 \\
\end{array}$ & 200 & 100 & $\begin{array}{c}\text { Extract } \\
50\end{array}$ & 25 & 12.5 \\
\hline S. aureus & $31.5 \pm 6.2$ & - & - & - & - & - \\
\hline S. typhi & $39.1 \pm 5.7$ & $11.3 \pm 0.2 *$ & - & - & - & - \\
\hline B. subtilis & $25.8 \pm 5.1$ & $14.5 \pm 1.1^{*}$ & - & - & - & - \\
\hline E. coli & $32.3 \pm 2.8$ & - & - & - & - & - \\
\hline
\end{tabular}

Key: (-) - No inhibition 
Table 8: In Vitro Minimum Inhibitory Concentration of the Acetone fraction of Garcinia kola Seed extract in Some Bacterial Isolates

\begin{tabular}{|l|ccccc|}
\hline Organism & \multicolumn{5}{|c|}{ Treatment (mg/ml) } \\
& $\mathbf{2 0 0}$ & $\mathbf{1 0 0}$ & $\mathbf{5 0}$ & $\mathbf{2 5}$ & $\mathbf{1 2 . 5}$ \\
\hline S. aureus & - & - & - & + & + \\
S. typhi & - & - & - & + & + \\
B. subtilis & - & + & + & + & + \\
E. coli & - & + & + & + & + \\
\hline
\end{tabular}

Key: (-) - No growth

(+)- Presence of growth

Table 9: In Vitro Antibacterial Activity of the Acetone fraction of Garcinia kola Seed extract in Some Bacterial Isolates. Values are mean zone of inhibition $(\mathrm{mm}),(\mathbf{n}=3)$

\begin{tabular}{|c|c|c|c|c|c|c|}
\hline Organism & $\begin{array}{c}\text { Treatment ( } \\
\text { Gentamicin } \\
4\end{array}$ & 200 & 100 & $\begin{array}{l}50 \\
50 \text { ract }\end{array}$ & 25 & 12.5 \\
\hline S. aureus & $31.5 \pm 6.2$ & $20.5 \pm 7.1 *$ & $11.1 \pm 6.5$ & $6.8 \pm 1.4^{\dagger}$ & - & - \\
\hline S. typhi & $39.1 \pm 5.7$ & $15.8 \pm 5.3^{*}$ & $6.1 \pm 1.7^{\dagger}$ & - & - & - \\
\hline B. subtilis & $25.8 \pm 5.1$ & $10.4 \pm 3.2 *$ & - & - & - & - \\
\hline E. coli & $32.3 \pm 2.8$ & - & - & - & - & - \\
\hline
\end{tabular}

\section{Key: (-) - No inhibition}

$* \mathrm{P}<0.05$ to control (gentamicin)

${ }^{\dagger} \mathrm{P}=<0.05$ compared to $200 \mathrm{mg} / \mathrm{ml}$ 
Table 10: In Vitro Minimum Inhibitory Concentration of the Ethyl Acetate fraction of Garcinia kola Seed extract in Some Bacterial Isolates

\begin{tabular}{|l|ccccc|}
\hline Organism & \multicolumn{7}{|c|}{ Treatment (mg/ml) } & & \\
& $\mathbf{2 0 0}$ & $\mathbf{1 0 0}$ & $\mathbf{5 0}$ & $\mathbf{2 5}$ & $\mathbf{1 2 . 5}$ \\
\hline S. aureus & - & - & + & + & + \\
S. typhi & - & - & - & + & + \\
B. subtilis & - & - & - & - & + \\
E. coli & - & + & + & + & + \\
& & & & & \\
\hline
\end{tabular}

Key: $\quad(-)$ - No growth

$(+)$ - Presence of growth

Table 11: In Vitro Antibacterial Activity of the Ethyl Acetate fraction of Garcinia kola Seed extract in Some Bacterial Isolates. Values are mean zone of inhibition $(\mathrm{mm}),(\mathrm{n}=3)$

\begin{tabular}{|c|c|c|c|c|c|c|}
\hline Organism & $\begin{array}{l}\text { Treatment } \\
\text { Gentamicin } \\
4 \\
\end{array}$ & 200 & 100 & $\begin{array}{c}\text { Extract } \\
50\end{array}$ & 25 & 12.5 \\
\hline S. aureus & $31.5 \pm 1.2$ & $14.5 \pm 3.2^{*}$ & $12.3 \pm 0.1$ & $\begin{array}{ll} & -\end{array}$ & - & - \\
\hline S. typhi & $39.1 \pm 1.7$ & $17.5 \pm 2.7 *$ & $15.8 \pm 1.1$ & $9.7 \pm 1.6^{\dagger}$ & - & - \\
\hline B. subtilis & $25.8 \pm 0.8$ & $15.1 \pm 0.5^{*}$ & $12.5 \pm 3.2$ & $11.8 \pm 2.1$ & $10.5 \pm 3.8^{\dagger}$ & - \\
\hline E. coli & $32.3 \pm 2.1$ & - & - & - & - & \\
\hline
\end{tabular}

Key: (-) - No inhibition

$* \mathrm{P}<0.05$ compared to control (gentamicin)

${ }^{\dagger} \mathrm{P}=<0.05$ compared to $200 \mathrm{mg} / \mathrm{ml}$

${ }^{\mathrm{a}} \mathrm{P}=>0.05$ compared to $200 \mathrm{mg} \cdot \mathrm{ml}$

\section{DISCUSSIONS AND CONCLUSION}

Fractionation of the crude methanol extract of Garcinia kola seeds indicates that the acetone fraction qualitatively presents similar phytochemical constituents as the crude fraction. The chloroform and n-hexane fractions presents only 1 and 2 constituents respectively out of the 9 analysed. The acetone fraction showed the presence of saponins and flavonoids more than the other fractions and this may perhaps explain it's relatively more antibacterial effect than the other fractions.

The crude methanol extract exhibited antibacterial activity against the bacterial isolates used in this investigation at $200 \mathrm{mg} / \mathrm{ml}$. However, these inhibitory effects were significantly less compared to those due to the reference antibiotic, gentamicin $(\mathrm{P}<0.05)$. The highest antibacterial activity was exhibited by the acetone fraction with a zone of inhibition of $20.5 \pm 7.1 \mathrm{~mm}$ against $S$ aureus at a concentration of $200 \mathrm{mg} / \mathrm{ml}$. This was however significantly lower compared to that due to gentamicin which presented a zone of inhibition of $31.5 \pm 6.2 \mathrm{~mm}$ on the same isolate $(\mathrm{P}<0.05)$. In the order of the diversity of their antibacterial activities, the methanol fraction appeared to have exhibited more diverse activity followed by ethyl acetate, acetone and chloroform fractions. The n-hexane 
fraction did not exhibit visible antibacterial activity. The antibacterial activity was dose-dependent with the largest zones of inhibition corresponding with the highest concentrations for the respective fractions and vice versa. The dose-dependent antibacterial activity was prominent with the methanol, acetone and ethyl acetate fractions where the zone of inhibition for each of the fractions at lower concentration was significantly less compared with those due to higher concentration of $200 \mathrm{mg} / \mathrm{ml}(\mathrm{P}<0.05)$. The most sensitive isolate was exhibited by $B$ subtilis at $200 \mathrm{mg} / \mathrm{ml}$ of the methanol fraction with a zone of $14.4 \pm 1.3 \mathrm{~mm}$. while the least sensitive was $E$ coli with zone of inhibition of $4.3 \pm 1.2 \mathrm{~mm}$. However, the antibacterial activity did not follow any particular pattern when compared with the polarity of the solvents used for the fractionation. The methanol fraction extracted with methanol ( $76.2 \%$ polarity) generally demonstrated a more diverse antibacterial action while the ethyl acetate fraction extracted with ethyl acetate (23.0\% polarity) exhibited the next most diverse antibacterial activity, which was more than that of acetone (35.5\% polarity). This suggests that the antibacterial activity exhibited by the fractions does not depend on polarity of the solvent. Generally, the minimum inhibitory concentrations showed that the most effective fraction could be the ethyl acetate component which exhibited the lowest MBC of 25 $\mathrm{mg} / \mathrm{ml}$ against $B$ subtilis with a zone of inhibition of $10.5 \pm 3.8 \mathrm{~mm}$. The antibacterial activity of the acetone fraction against $S$ aureus exhibited the largest zone of inhibition of $20.5 \pm 7.1 \mathrm{~mm}$ at the concentration of $200 \mathrm{mg} / \mathrm{ml}$, suggesting it as the most effective among the fractions on this isolate. This was however significantly lower compared with that due to gentamicin $(\mathrm{P}<0.05)$.

The isolates are all typical model microorganisms that are often used for better understanding infectious disease in clinical settings. This therefore suggests that the results could be relevant in the treatment of infectious diseases caused by these or related agents in man.

The antibacterial activity of Garcinia kola has been reported from previous investigations by other workers [25. 16. 26, 27, 28]. However, most of such findings have not addressed conclusively the exact constituent responsible for the antibacterial activity. Nonetheless, the antibacterial activity may perhaps be attributed to the presence of saponins $[29,20,31]$, tannins [32. 33] or flavonoids [34] either as single entities or in synergy with each other. This is because these phytochemicals were commonly present in the ethyl acetate, acetone and methanol fractions which exhibited relatively higher antibacterial activities than chloroform which exhibited same activity in $S$ aureus and B subtilis only at higher concentration of $200 \mathrm{mg} / \mathrm{ml}$ while $\mathrm{n}$-hexane with only presence of carbohydrates, steroids and cardiac glycosides did not exhibit any antibacterial activity in any of the isolates.

In conclusion, the findings from this study may contribute to further understanding of the constituents that could be responsible for the antibacterial activity exhibited by the crude methanol extract of Garcinia kola seeds.

\section{Acknowledgement}

We wish to express our gratitude to Mr Thomas Yakubu of Pharmacognosy and Medicinal Plant Research Department and also to Mrs Rebecca Mbule of the Department of Pharmaceutical Microbiology, all of the Faculty of Pharmaceutical Sciences, University of Jos, for their technical assistance in this course of this study.

\section{Conflict of Interest}

There was no conflict of interest declared by any of the authors on this study

\section{References}

[1] Kowti R., Harsha R, Ahmed MG, Hareesh AR, Gowda TSS, Dinesha R, Kumar SBP, Ali IM (2010). Antimicrobial activity of ethanol extracts of leaf and flower of Spathodea

[2] Cragg GM., Grothaus PG., Newman, DJ. (2009). Impact of natural products on developing new anti-Cancer Agents. Chemical Rev 109(7): 3012-3043.

[3] World Health Organization (2015). Antimicrobial resistance. Fact sheet No 194, available on WWW.WHO.int/mediacentre/factsheets/fs194/en/.

[4] Desai, MN, Chavan, NS (2010). Antibacterial activity and phytochemical screening of Cynometra iripa Kostel. Int J Pharmacol Biol Sci 1(3), 1-4.

[5] Ernst, E (1998). Harmless herbs? A review of the literature. The Am J Med 104(2), 170 - 178. 
[6] Adegoke G. O, Vijay K. M., Sambaiah K., Lolash B.R (1998). Inhibitory effect of Garcinia kola on lipid peroxidation in rat liver homogenates. Indian J Exp Biol 36(9): 907-910

[7] Iwu M.M, Onwuchekwa, U. A; Okuni C.O (2002): Evaluating the anti-hepatotoxic active of the bioflavonoids of Garcinia kola seed. J Ethnophamacol 127-136.

[8] Iwu M. M (1999). Garcinia kola; a new adaptogen with remarkable immune-stimulant, anti-infective and anti-inflammatory properties. Abstract of the Int. Conf.on ethnomed and drug discovery, Silver Spring Mary land, USA, Nov. pp. 1-26.

[9] Farombi EO, Adeposu BF, Oladaries OE, Emerole CO (2005). Chemoprevention of Aflatoxin B1-induced genotoxicity and hepatic oxidative damage in rats by kolaviron a natural biflavonoids of Garcinia kola seeds. Eur J Cancer Prev 14: $207-214$.

[10] Adesuyi, AO, Elumm IK., Adaramola FB. and Nwokocha AGM. (2011). Nutritional and Phytochemical Screening of Garcinia kola. Nig Adv J Food Sci Technol 4(1): 9- $\quad$ 14, ISSN: 2042-4876.

[11] Kabangu L, Galeffi C, Aonzo E, Nicoletti M, Messana I (1987). New biflavone from the bark of G. kola. Planta Medica, 11:27527.

[12] Naiho AO, Ugwu AC (2009). Blood Pressure Reducing Effect of Bitter Kola (Garcinia kola, Heckel) in Wistar Rats. Afr J Biomed Res 12(2):131134.

[13] Nwaneri-Chidozie VO, Anyanwu OA, Adaramoye OA, Emerole O (2014). Cardio-protective effect of Kolavion (Garcinia kola seed extract) in cholesterol fed rats. Int J Pharma Sci Res. 5(3): 96-99.

[14] Adaramoye O. A, Nwaneri V.O., Anyanwu K.C., Farombi E.O., Emerole G.O (2005). Possible anti- atherogenic effect of kolaviron (A Garcinia kola seed extract) in hypercholesterolemic rats. Clin Exp Pharmacol Physiol 32(1-2):40-46.

[15] Onyemaechi OA, Osinubi AA, Noronha CC, Okanlawon AO (2005). Hypoglycaemic Activities of Extract of Garcinia Kola seeds in normal, hyperglycemic and alloxan-Induced diabetic rats. W Afr J Med 8:141-149.

[16] Adegboye MF, Akinpelu DA, Okoh AI (2008). The bioactive and phytochemical properties of Garcinia kola seed extract on some pathogens. Afr J Biotechnol 7(21): 3934-3938.

[17] Otsuka H (2006). Purification by solvent extraction using partition coefficient. In: SD Sarker, Z Lafif, GI Alexander, editors. Methods in biotechnology: Natural product isolation. 2nd ed. Totowa, New Jersey, USA: Human Press Inc; 2006 Trease G, Evans WC. Pharmacognosy. 12th ed. London: Baillere Tindall; 1983, p387, 475-476.

[18] Trease G, Evans W (2009). Pharmacognosy. 16 th Edition, London, Billere Tindall, 2009, UK.

[19] Joshi A, Bhobe M, Saatarkar A (2013). Phytochemical investigation of the roots of Grewa microcos. J Chem Pharm Res 5: 8087.

[20] Igbal E, Salim KA, Lim LBL (2015). Phytochemical screening, total phenolic and antioxidant activities of bark and leaf extracts of Ganiothalamus velutinus (Airy Show) from Brunei Darussalam. J King Saud Uni-Sci 27: 224-232.

[21] Ayoola GA, Coker HB, Adesegun SA, Adepoju-Bello AA, Obaweya K, Ezennia EC, (2008). Phytochemical screening and antioxidant activities of some selected medicinal plants used for malaria therapy in Southwestern Nigeria. Trop J Pharm Res 7: 1019-1025.

[22] Stanley B, Walton G (1968). Preparation of Agar Wells for Antibiotic Assay. Microbiology Department, Abbott Laboratories, www.scirj.org

(C) 2019, Scientific Research Journal

http://dx.doi.org/10.31364/SCIRJ/v7.i5.2019.P0519649 
North Chicago, Illinois 60064.

[23] Ndukwe IG, Bello AI, Habila JD, John C (2007). Phytochemical and antimicrobial screening of the crude petroleum spirit and methanol extracts of the stem bark, leaves and roots of Ficus thonigii (blume). Afr J Biotechnol 6: 2645-2649

[24] Cleidson V, Simone M, Elza FA, Arthur S (2007). Screening Methods to Determine Antibacterial Activity of Natural Products. Brazilian J Microbiol 38: 369-380, doi: 10.1590/S1517-8382200700033

[25] Madubunyi II (1995). Antimicrobial activities of the constituents of Garcinia kola seeds. Int J Pharmacog 33(3): 232-237, doi: $10.3109 / 13880209509065369$

[26] Akinpelu DA, Adegboye MF, Adeloye AO, Okoh AI (2009). Biocidal activity of partially purified fractions from methanolic fractions of Garcinia kola (Heckel) seeds on bacterial isolates. Biol Res 41(3): 277-287, doi: /50716-97602000300005

[27] Njume C, Afolayan AJ, Clark AM, Ndip RN (2011). Crude ethanol extract of Garcinia kola seeds (Heckel) prolonged the lag phase of Helicobacter pylori: inhibitory and bactericidal potential. J Med Food 14(7-8): 822-7 doi: 10.1089/jmf.2011.0127

[28] Okwonkwo EC, Nworie O, Nwuzo AC, Onwa AC, Odu-Ibiam EO, Oke B, Nwosu UA, Nwekwete MA (2017). Antimicrobial effects of Bitter Kola (Garcinia kola) nut on Staphylococcus aureus, Escherica coli and Candida albicans. W J Med Sci 14(3): 89-96, doi: 10.5829/idosi.wjms.2017.89.96

[29] Soetan KO, Oyekunle MA, Aiyelaabe OO, Fafunsho MA (2006). Evaluation of the antimicrobial activity of saponin extract of sorghum. Afr J Biotechnol 5(23): 2405-2407

[30] Arabski M, Wedierek-Ciuk A, Czerwonka G, Lankoff A, Kaca W (2012). Effects of saponin against clinical E coli strains and Eukaryotic cell line. J Biomed Boitech Volume 12 Article LD 286216, doi: 10.1155/2012/286216

[31] Maatalah MB, Bouzidi NK, Bellhouel S, Merah B, Fortas Z, Soulimani R, Saidi S, Derdour A (2012). Antimicrobial activity of the alkaloids and saponins extract of Anabosis articulate. J Biotechnol Pharm Res 3(3): 54-57

[32] Min BR, Pinchak WE, Anderson RC, Callaway TR (2007). Effect of tannins on in vitro growth of $E$ coli O157: $H 7$ and in vivo growth of generic E coli excreted from steers. J Food Protection 70(3); 543-550

[33] Akiyamo H, Fujii K, Yamasaki O, Oono T, Iwatsuki K (2001). Antibacterial action of several tannins against Staphylococcus aureus. J Antimicr Chem 48(4): 487-491, doi: 10.1093/jac/48.4.487

[34] Wafa N, Sofiane G, Mohammed K (2016). The antioxidant and antimicrobial activities of flavonoids and tannins extracted from Phlomis bovei. Eur J Exp Biol 6(3): 55-61 